\title{
Assessment of the Impact of Wild Stinkhorn Mushroom Extracts on Different Cancer Cell Proliferation and Study of Primary Metabolites
}

\author{
Ribhu Ray, Amrita Pal, Santanu Paul*
}

Ribhu Ray, Amrita Pal, Santanu Paul*

Laboratory of Cell \& Molecular Biology, Department of Botany, University of Calcutta, Kolkata 700019, INDIA.

\section{Correspondence}

\section{Santanu Paul}

Laboratory of Cell and Molecular Biology, Department of Botany, University of Calcutta, 35 Ballygunge Circular Road Kolkata 700019, West Bengal, INDIA. Phone no: +91 9874192648;

\section{Fax: +91 3323546623;}

E-mail: spaul_1971@yahoo.com History

- Submission Date: 12-02-2020;

- Review completed: 18-03-2020;

- Accepted Date: 11-04-2020.

DOI : 10.5530/pj.2020.12.102

Article Available online http://www.phcogj.com/v12/i4

\section{Copyright}

(C) 2020 Phcogj.Com. This is an openaccess article distributed under the terms of the Creative Commons Attribution 4.0 International license.

\begin{abstract}
Objective: Present study aims to evaluate the efficacy of methanolic and ethyl acetate extracts of wild mushroom Phallus sp. on cell proliferation of both normal and cancer cells. This study also looked at anti-oxidant potentiality of methanolic extract and also unravels the phytochemical profiling of both extracts. Methods: Anti-proliferative activity was assessed by MTT assay on different human cancer cell lines such as MCF-7, MOLT-4, REH and Peripheral Blood Mononuclear Cells or PBMC isolated from a healthy donor. Gas Chromatography-Mass Spectrometry (GC-MS) analysis was used for comparative assessment of phytochemical constituents of both extracts. The anti-oxidant profile of methanolic extract was also evaluated by DPPH and ABTS + assays. Results: Results indicated that the both methanolic and ethyl acetate extracts of Phallus sp. showed appreciable anti-proliferative activity against breast cancer cell line MCF-7 with $I_{50}$ of $8.544 \pm 2.812 \mu \mathrm{g} / \mathrm{mL}$ and $35.279 \pm 2.863 \mu \mathrm{g} / \mathrm{mL}$ respectively. Both of the extracts also showed its moderate impact on human $B$ cell precursor leukemia cell line $(R E H)$ with $I C_{50}$ of $25.987 \pm 2.696 \mu \mathrm{g} / \mathrm{mL}$ for methanol and $51.484 \pm 1.480 \mu \mathrm{g} / \mathrm{mL}$ for ethyl acetate extract respectively. No effect was observed in MOLT-4 cell line. Methanolic extract was selected as better anti cancer extract over ethyl acetate extract. No significant anti-proliferative activity was observed in normal PBMC by both extracts. GC-MS analysis indicated that 43 and 114 compounds were identified from methanolic and ethyl acetate extracts respectively. Among them nine compounds shared its existence in both of the extracts. Different derivatives of ergosterol and several fatty acid esters ware identified as major components from both of the extracts. Methanolic extracts of the Phallus sp. showed its effectiveness on both of DPPH and ABTS $\bullet+$ free radical, and result indicated that it contain more flavonoid content than phenol. Conclusion: The methanolic extract of Phallus sp. show very specific anti-proliferative effect on MCF-7 with moderate anti-oxidant activity and holds a great promise for isolation of bio molecules for treating Breast Cancer. Several derivatives of ergosterol identified as probable anti-cancer compound.
\end{abstract}

Key Words: MTT assay, GC-MS, Phallus, MCF-7, ABTS•+.

\section{INTRODUCTION}

Cancer is identified as the first or second leading cause of death in 91 to 172 countries and it is also ranked as third and fourth in an additional 22 countries $^{1,2}$. Cancer is one of the major public health problem and the second leading cause of death in the United States ${ }^{3}$. It has been estimated that in 2020,1,806,590 new cancer cases may occur in United States and among them 606,520 cancer death has been projected ${ }^{3}$. In India cancer is ranked as second leading cause of death in the urban area and placed at fourth in rural areas. In India, 1.15 million new cancer patients were recorded in 2018, and it is predicted to almost double by $2040^{4}$. Cancer is characterized by uncontrolled cell proliferation and it may appear in different forms such as lung, breast, colon, skin, blood cancer etc. ${ }^{5}$. In India, it is now cause of catastrophic health spending, calamity financing and rising expenditure before death ${ }^{4-8}$. The invasiveness and mortality rate of the cancer vary among different forms, lung cancer is highly fatal with a very high death rate of $70 \%$, followed by colon cancer and breast cancer ${ }^{5}$.

The most commonly used potential strategy for treating cancer is the use of various chemotherapeutic drugs along with radiotherapy ${ }^{9}$. Chemotherapeutic drug should be target specific to cancer cells, and should not affect the normal cells. But most of the chemotherapeutic drugs available in the market, show various adverse effects on the normal cells ${ }^{10,11}$. There is an urgent need for the further development of safe anticancer drugs to counteract these negative consequences of the existing drugs. This study aims at the identification of alternative anti-cancer drugs preferably from natural sources with minimal collateral damages to normal cells ${ }^{12}$. Mushroom contain wide range of bioactive compound such as different variety of phenols and flavonoids ${ }^{13}$, polysaccharides, glycosides, alkaloids, volatile oils, tocopherols, carotenoids, organic acids ${ }^{14}$ and may act as a potential alternative substitute for naturally occurring anti-oxidants, anticancer,

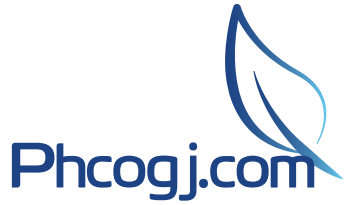

Cite this article: Ray R, Pal A, Paul S. Assessment of the Impact of Wild Stinkhorn Mushroom Extracts on Different Cancer Cell Proliferation and Study of Primary Metabolites. Pharmacogn J. 2020;12(4):699-708. 
immunomodulating, anti-inflammatory, cardiovascular, anti-microbial and anti-diabetic drug ${ }^{15-19}$.

The stinkhorn-- (genus Phallus Junius ex L.) is classified under the family of Phallaceae of order Phallales, which are easily identified by its foetid odour, saccate rhizomorph containing volva, unbranched sponge like pseudostipe with extremely attached olive brown to dark brown slime containing the spore mass (gliba) and occasionally a skirtlike indusium ${ }^{20}$. All species under the Phallaceae are short-lived ${ }^{21}$, begin their development as an oval or round shaped structure termed as "eggs" (early stage of basidiocarp) but mature basidiocarp show drastic variation of colour and pattern, thus distinguish different species of this genus $^{2021}$. The mature spore mass produces a characteristic carrion like smells which attracts different insects to disperse the spore, and make it one of the most easily recognizable species of fungi. According to Index Fangorum 2016, genus Phallus contains 31 species. Reported Phallus species show wide range of distribution pattern in different climate type from tropical, subtropical and temperate forest but predominantly occupying the tropical and subtropical habitat ${ }^{22-26}$.There are a large number of Phallus sp. reported from different habitat and location of India ${ }^{2026-28}$

So, in this present study we have tried to assess the impact of both ethyl acetate and methanolic extracts of wild stinkhorn (Phallus sp.) on different cancer line (MCF-7, MOLT-4, REH) in vitro and try to compare the phytochemical constituents profiling of two extracts through GC-MS analysis. The antioxidant profile of the methanolic extract of this mushroom was also evaluated.

\section{MATERIALS AND METHOD}

\section{Chemicals}

All chemicals used were of analytical grade and freshly prepared. RPMI 1640 (Sigma Aldrich), DMEM (Sigma Aldrich), FBS (Sigma Aldrich), Penicillin and Streptomycin (Sigma Aldrich), MTT [3(4,5 dimethylthiazol-2-yl)-2,5-diphenyltetrazolium bromide (Sigma Aldrich), DMSO, Phosphate Buffer Saline (Himedia) , 2, 2-Diphenyl-1picrylhydrazyl (DPPH) (SRL) , 2, 2'-azinobis (3-ethylbenzothiazoline6-sulfonic acid) (ABTS) (Sigma-Aldrich), sodium persulfate (SRL) , Gallic acid (Merck), Sodium carbonate (Merck), Folin Ciocalteau (Merck), Methanol, Ethyl acetate, Hexane,. Quercetin (SRL), Sodium nitrite (Himedia), Aluminum chloride (Merck).

\section{Sample collection and identification}

The fresh mature fruit body of Phallus was collected from Lolegaon $\left(27^{\circ} 00^{\prime} 50.6^{\prime \prime} \mathrm{N} 88^{\circ} 33^{\prime} 40.4^{\prime \prime} \mathrm{E}\right)$, a small Lepcha village of Kalimpong district of West Bengal during the month of May 2019 .Their morphological characteristics such as color, size, shape were recorded on spot immediately after collection.

\section{Molecular identification of the mushroom}

DNA extraction-Total genomic DNA was extracted from the airdried specimen $(38 \mathrm{mg}$ ) by using the Fungal gDNA Mini Kit (Xcelris Genomics, Ahmedabad, India) following the manufacturer instructions.

Polymerase Chain Reaction (PCR)- Internal transcribed spacer (ITS) region 1,2 and the $5.8 \mathrm{~s}$ rDNA were amplified by using a pair of primer sequence ITS1 (forward primer 5' TCC GTA GGT GAA CCT GCG G 3') and ITS4 (reverse primer 5' TCC TCC GCT TAT TGA TAT GC $\left.3^{\prime}\right)^{29}$. The PCR reaction mixture were contained following components :10X PCR buffer (Thermo\#EP0702) , 8X dNTP mix $2 \mathrm{mM}$ each (Thermo \#R0241) , $100 \mathrm{mM}$ of each primer, $30 \mathrm{ng}$ of extracted genomic DNA, $5 \mathrm{U} / \mu \mathrm{L}$ Taq DNA polymerase (Thermo\#EP0702), $20 \mathrm{mM} \mathrm{MgCl}$ (Thermo\#EP0702) and nuclease free water to make final volume 50 $\mu \mathrm{L}$. Amplification reaction was performed by using 96 well thermal cycler (Veriti, Applied Biosystems) programmed as initial denaturation for $4 \mathrm{~min}$ at $94^{\circ} \mathrm{C}$ followed by 35 cycles consisting of 1 minutes at $94^{\circ} \mathrm{C}$ (denaturation) then $1 \mathrm{~min}$ in $56^{\circ} \mathrm{C}$ for annealing, $1 \mathrm{~min}$ at $72^{\circ} \mathrm{C}$ (extension) and finally one cycle for $10 \mathrm{~min}$ at $72^{\circ} \mathrm{C}$ for final elongation.

The PCR amplicons were checked by electrophoresis on $2 \%$ agarose gel containing ethidium bromide.

Sequencing- PCR amplicons were then further purified and were subjected to automated DNA sequencing on an ABI3730XL-15104-028 DNA Analyzer (Applied Biosystems, USA) using same sets of primers identical with amplicons for the ITS rDNA region. The newly generated sequences were then deposited in GenBank (www.ncbi.nlm.nih.gov).

\section{Extraction procedure}

Fresh material was air-dried and grinded by mixer grinder. Powdered basiodiocarp $(5 \mathrm{~g})$ was first defatted with $50 \mathrm{~mL}$ of hexane for 48 hours. After that residue was air-dried and extracted with $50 \mathrm{~mL}$ of ethyl acetate for 48 hours. The mixture was filtered through whatman- 4 and then lyophilized to ethyl acetate fraction (EAP). The residue was further re-extracted with $50 \mathrm{~mL}$ methanol 48 hours and same procedure was followed for obtaining methanol fraction (MEP).

\section{Cell line and culture}

MCF-7 (human breast cancer cell line), MOLT-4 (human acute T lymphoblastic leukaemic cell line), REH (human B cell precursor leukemia cell line) cell lines were used for the evaluation of antiproliferative activity of both EAP and MEP extracts. Above cell lines were cultured in either DMEM or RPMI 1640 supplemented with 2 $\mathrm{mM} \mathrm{L}$-glutamine, $10 \%(\mathrm{v} / \mathrm{v}) \mathrm{FBS}$ (heat inactivated), $10 \mathrm{U} / \mathrm{mL}$ penicillin and streptomycin and incubated at $37^{\circ} \mathrm{C}$ in a humidified atmosphere of $5 \% \mathrm{CO}_{2}$ incubator (HF90).

\section{Cell viability assay}

In order to determine the impact of both EAP and MEP extracts on cell proliferation, MTT assay ${ }^{30}$ was performed. Briefly, $5 \times 10^{4}$ cells was seeded in 96-well cell culture plate in presence of MEP and EAP (10$100 \mu \mathrm{g} / \mathrm{mL}$ ) for $48 \mathrm{~h}$. After that, cell culture media was replaced with $5 \%$ FBS-containing phenol red-free DMEM and MTT $(200 \mu \mathrm{L} ; 0.5 \mathrm{mg} / \mathrm{mL})$ and incubated for $4 \mathrm{~h}$ in a humidified incubator containing $5 \% \mathrm{CO}_{2}$. Finally, the media was discarded and formazan crystals was dissolved in DMSO and was measured at $560 \mathrm{~nm}$ (iMark, Biorad). 5\% SDS lyses buffer was used for making the $100 \%$ full lysed cell and it was also spectrophotometrically measured at $560 \mathrm{~nm}$ (iMark, Biorad). The percentage of cell viability was calculated according to the following equation: $\%$ cell viability $=$ (O.D. sample - O.D. 100\%lysis) $/$ (O.D. $0 \%$ lysis - O.D. $100 \%$ lysis $) \times 100$.

\section{Comparative phytochemical profiling of EAP and MEP by Gas Chromatography-Mass Spectrometry (GC-MS)} analysis

Phytochemical investigation of both EAP and MEP extracts were performed by gas chromatographic analysis 7890A (Agilent Technologies) coupled with a mass spectrometer (MSD 7000). For gas chromatographic analysis a capillary non-polar column HP-5MS (5\% Phenyl Methyl Silox: Agilent 19091S-433) with the dimension of $30 \mathrm{~m}$ X $250 \mu \mathrm{m}$, along with film thickness: $0.25 \mu \mathrm{m}$ was used. Helium was used as a mobile phase with a flow rate of $2.25 \mathrm{~mL} \mathrm{~min}^{-1}$. The injection volume of the sample was $1 \mu \mathrm{L}$ with a split ratio of $2: 1$ at $320^{\circ} \mathrm{C}$. The oven was programmed at $60^{\circ} \mathrm{C}$, then raised to $320^{\circ} \mathrm{C}$ for $12 \mathrm{~min}$ at $6{ }^{\circ} \mathrm{C}$ $\mathrm{min}^{-1}$ rate. For mass spectrometric analysis the system was programmed in full scan, with electron impact $70 \mathrm{eV}$ in a range of 50-550 (m/z). The compound was identified by comparing its fragmentation profile with spectra present in the library NIST version 2.2. 


\section{Evaluation of antioxidant potential of MEP}

The DPPH and ABTS $\bullet+$ free radical scavenging assay are widely used methods for evaluation of the antioxidant capacities of natural products ${ }^{31}$. This aforementioned assays are performed by spectrophotometric techniques based on the quenching of stable colour radicals (DPPH and ABTS $\bullet+$ ) and thus indicate the radical scavenging potentiality of antioxidant compounds even when present in complex biological mixtures ${ }^{31}$.

To determinate the impact of MEP on artificially generated free radical, DPPH free radical scavenging assay and $\mathrm{ABTS} \bullet+$ free radical scavenging assay were carried out.

\section{DPPH free radical scavenging Assay}

The free radical scavenging activity of the MEP on DPPH radicals was measured according to the method of Hajra et al..$^{32}$ and Brand-Williams et al..$^{33}$ with slight modification. Briefly $0.9 \mathrm{~mL}$ of DPPH solution $(0.1 \mathrm{mM})$ was added to a test tube of $100 \mu \mathrm{L}$ mushroom extract, concentration range $100-500 \mu \mathrm{g} / \mathrm{mL}$ diluted with methanol. Control was prepared with methanol instead of the mushroom sample. The reaction mixture was incubated for $2 \mathrm{~h}$ at room temperature and the absorbance was measured at $515 \mathrm{~nm}$ with a spectrophotometer (Shimadzu). The percent of reduction of DPPH was calculated according to the following equation: \% DPPH reduction $=[\{(\mathrm{Ac}-\mathrm{As}) / \mathrm{Ac}\} \times 100]($ Where; $\mathrm{As}$ is the absorbance of sample, Ac is the absorbance of control).

\section{ABTS•+ free radical scavenging assay}

The free radical scavenging activity of the MEP on ABTS $\bullet+$ radicals was measured according to the method of Re et al. ${ }^{34}$ with slight modification. The long-lived ABTS $\bullet+$ radical cation chromophore 2, 2 ' -azinobis-(3ethylbenzothiazoline-6-sulphonate) was generated by reacting $7 \mathrm{mM}$ of ABTS stock solution (prepared in deionised water) with $2.45 \mathrm{mM}$ potassium persulfate (prepared in deionised water) at a ratio $1: 1(\mathrm{v} / \mathrm{v})$ and the mixture was incubated in the dark at room temperature for twelve hours before use. Working solution of ABTS•+ was prepared by diluting ABTS stock solution with $5 \mathrm{mM}$ phosphate buffer solution (PBS), pH 7.4, and equilibrated an absorbance of $0.7( \pm 0.2)$ at $734 \mathrm{~nm}$ at $30^{\circ} \mathrm{C}$. The assay was performed in 96 wall microplate by following protocol, $10 \mu \mathrm{L}$ of methanolic extract (concentration range, 100-500 $\mu \mathrm{g} /$ mL diluted methanol) of mushroom were mixed with $290 \mu \mathrm{L}$ of ABTS •+ working solution and incubated for ten minutes at $37^{\circ} \mathrm{C}$. The reduction of ABTS •+ radical by mushroom extract, containing antioxidant compounds was measured by the change of absorbance of ABTS •+ radical at $734 \mathrm{~nm}$ (Shimadzu). The percent of reduction of ABTS•+ was calculated according to the following equation: $\%$ ABTS $\bullet+$ reduction $=$ $[\{(\mathrm{Ac}-\mathrm{As}) / \mathrm{Ac}\} \times 100]$ (Where; As is the absorbance of sample, Ac is the absorbance of control.)

\section{Assessment of antioxidant compound present in MEP}

The antioxidant potentiality of the mushroom extract depends on the antioxidant compound present in the extracts. The phenol and flavonoid are the major antioxidant compounds present in biological mixtures. So the total phenol and flavonoids content of MEP were also quantitatively evaluated.

\section{Total Phenolic content determination}

Total phenolic content of MEP was quantitatively measured by the method of Singleton et al. ${ }^{35}$ and Mridha et al. ${ }^{36}$ using Folin-Ciocalteu reagent with vary minor modification. $200 \mu \mathrm{L}$ of mushroom extract was mixed with $1 \mathrm{~mL}$ of Folin-Ciocalteu reagent. After 5 minutes, 0.8 $\mathrm{mL}$ of $10 \%$ sodium carbonate solution was added and volume was adjusted with help of $50 \%$ methanol. Then the mixture was incubated in dark for 20 minutes and finally the absorbance was read at $765 \mathrm{~nm}$ by spectrophotometer. Different concentration of Gallic acid (0-10 $\mu \mathrm{g} /$ $\mathrm{mL}$ ) was used as a standard. Finally, the result was expressed as $\mathrm{mg}$ of Gallic acid equivalent (GAEs) present per g of mushroom dry weight.

\section{Total flavonoid content determination}

Total flavonoid content of MEP was quantitatively assessed by following the method of Shing et al. ${ }^{37}$ using aluminium chloride colorimetric method . Briefly $200 \mu \mathrm{L}$ of mushroom extract was diluted with $1 \mathrm{~mL}$ of double distilled water and then $75 \mu \mathrm{L} 5 \%$ sodium nitrate solution was added. After 6 minutes of incubation $75 \mu \mathrm{L}$ of $10 \%$ aluminium chloride solution was added to the reaction mixture and kept for 5 minutes in room temperature. Finally, $500 \mu \mathrm{L}$ of $1 \mathrm{M}$ sodium hydroxide solution was added to the mixture, and it was vortexed and absorbance was taken at $510 \mathrm{~nm}$. Different concentration of Quercetin (10-100 $\mu \mathrm{g} /$ $\mathrm{mL}$ ) was used as a standard. Finally, the result was expressed as mg of Quercetin equivalent (QEs) present per g of mushroom dry weight.

\section{RESULT}

\section{Identification of the mushroom by DNA Barcoding}

DNA barcoding is one of the most emerging molecular technique for identification and taxonomic revision of the biological specimen ${ }^{38-40}$. DNA sequence based specimen identification method was applied for this present study to verify the morphologically identified species. Genomic DNA extracted from this specimen was amplified with combination of both ITS1 and ITS4 primers and $365 \mathrm{bp}$ long stretch of DNA sequence was generated. The generated sequence was submitted to gene bank with accession number MT007520. The closest hit of MT007520 was Phallus coronatus (GenBank : MG678522), sequence identity=313/324 (97\%); gaps= 4/324 $(1 \%)$.

\section{Cell viability assay}

Both EAP and MEP extracts of Phallus showed very effective antiproliferative activity in vitro when subjected to MTT assay at the time point of 48 hours (Figure 1). $\mathrm{IC}_{50}$ is the particular concentration of the drug, where $50 \%$ of cancer cells are killed. The $\mathrm{IC}_{50}$ of both MEP and EAP against different cancer cell line were represented on Table 1 (Figure 1C). The $\mathrm{IC}_{50}$ value of MEP against the MCF-7 and REH were $8.544 \pm 2.812 \mu \mathrm{g} / \mathrm{mL}$ and $25.987 \pm 2.696 \mu \mathrm{g} / \mathrm{mL}$ respectively. $\mathrm{IC}_{50}$ value of EAP against the MCF-7 and REH were $35.279 \pm 2.864 \mu \mathrm{g} / \mathrm{mL}$ and $51.484 \pm 1.481 \mu \mathrm{g} / \mathrm{mL}$ respectively. MOLT- 4 cell line showed minimal activity than aforementioned two cell lines. $\mathrm{IC}_{50}$ value of MOLT- 4 cell line were $131.266 \pm 9.806 \mu \mathrm{g} / \mathrm{mL}$ against MEP extract and $126 \pm 2.111 \mu \mathrm{g} /$ $\mathrm{mL}$ against EAP extract. Both extracts showed very negligible cytotoxic activity against Peripheral Blood Mononuclear Cells or PBMC isolated from healthy donor (Figure 1A,1B). So, it can be assumed that both extract of Phallus showed the specific cytotoxic effect on cancer cells, no such derivation on the ground of cell viability were recorded from normal PBMC cells.

Comparative study of photochemical profiling of EAP and MEP by Gas Chromatography-Mass Spectrometry (GC-MS) analysis

GC-MS chromatogram of both MEP and EAP were represented in Figure 2 and Figure 3 respectively. Total 43 and 114 compounds were identified by comparing its fragmentation profile with spectra present in the library NIST version 2.2. Among them the major compounds which occupied minimum $1 \%$ of total area were listed in Table 2 for EAP and Table 3 for MEP respectively. Total 16 major compounds were found in MEP and 29 major compounds were found in EAP and 9 compounds were shared by both of extracts.

EAP extract were contained two major compounds namely ergosta5,22-dien-3-ol,(3ß,22E,24S) and 9,12-octadecadienoic acid (Z,Z) 
Table 1: Comparative analysis of $\mathrm{IC}_{50}(\mu \mathrm{g} / \mathrm{mL})$ values of EAP and MEP of Phallus sp. tested in the following cell line through MTT assay. Results are the mean value of three independent experiments with standard deviation.

\begin{tabular}{ccc}
\hline Cancer cell line & \multicolumn{1}{c}{$\mathrm{IC}_{50}(\mu \mathrm{g} / \mathrm{mL})$} & $\mathrm{MEP}$ \\
\hline MCF-7 & EAP & $8.544 \pm 2.812$ \\
REH & $35.279 \pm 2.863$ & $25.987 \pm 2.696$ \\
MOLT-4 & $51.484 \pm 1.480$ & $131.266 \pm 9.805$ \\
\hline
\end{tabular}
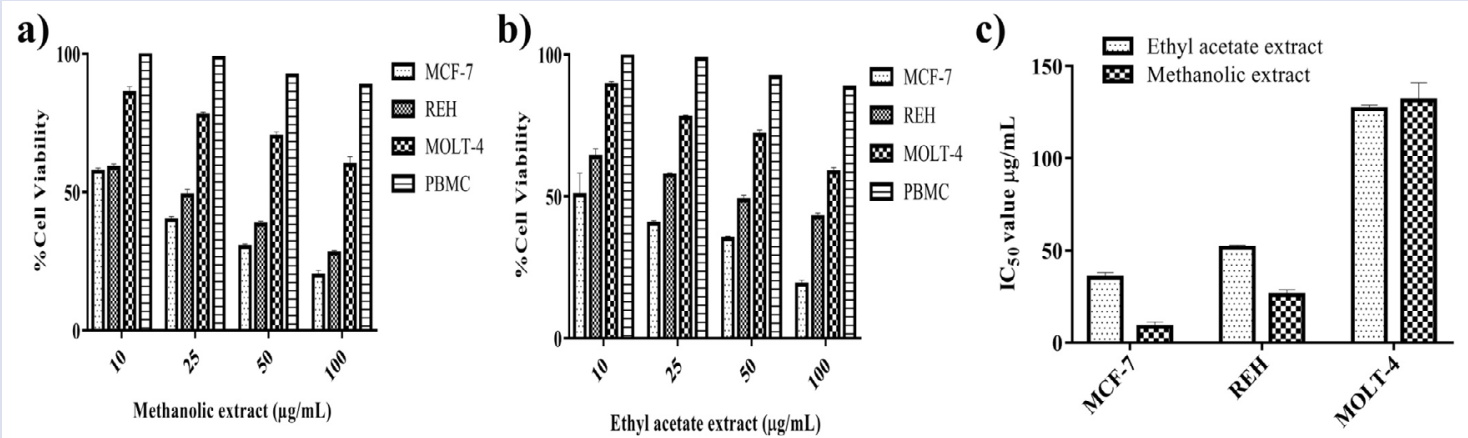

Figure 1: Selective anti-proliferative activity of EAP and MEP extracts of Phallus sp. (10-100 $\mu \mathrm{g} / \mathrm{mL}$ ) on different cancer cell lines including MCF-7, REH, MOLT-4 and normal cell PBMC. A) Methanolic extract (MEP), B) Ethyl acetate extract (EAP), C) Comparative account of $\mathrm{IC}_{50}$ values.

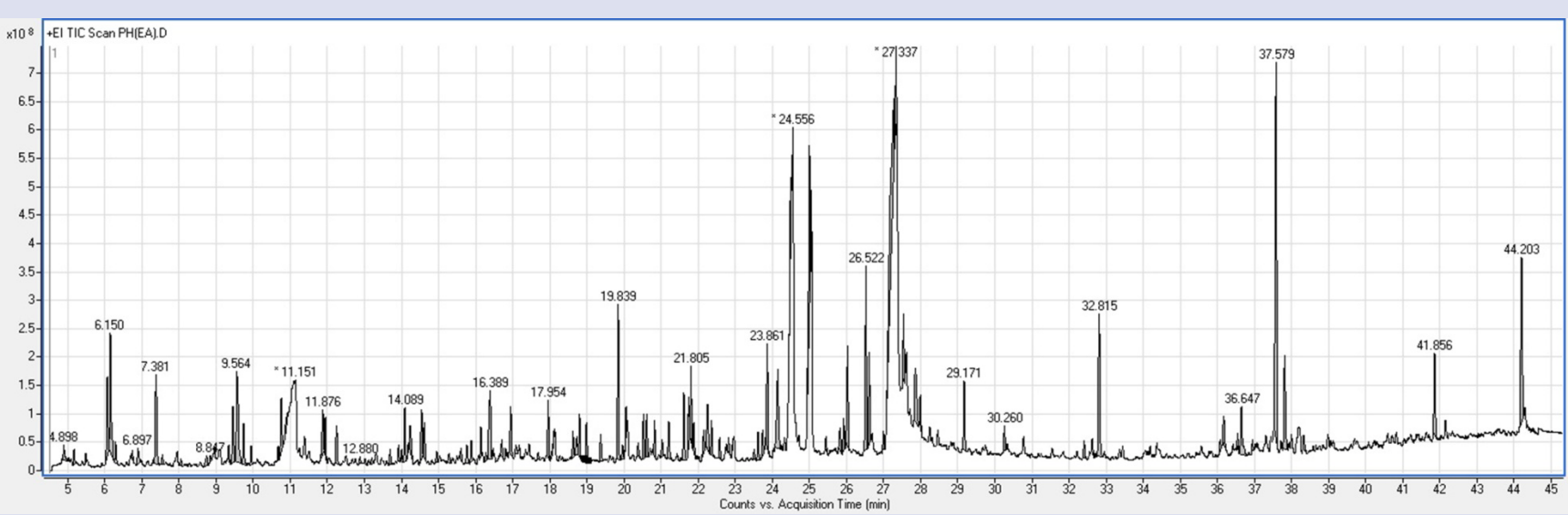

Figure 2: GC-MS chromatogram of Ethyl acetate extract of (EAP) of Phallus.

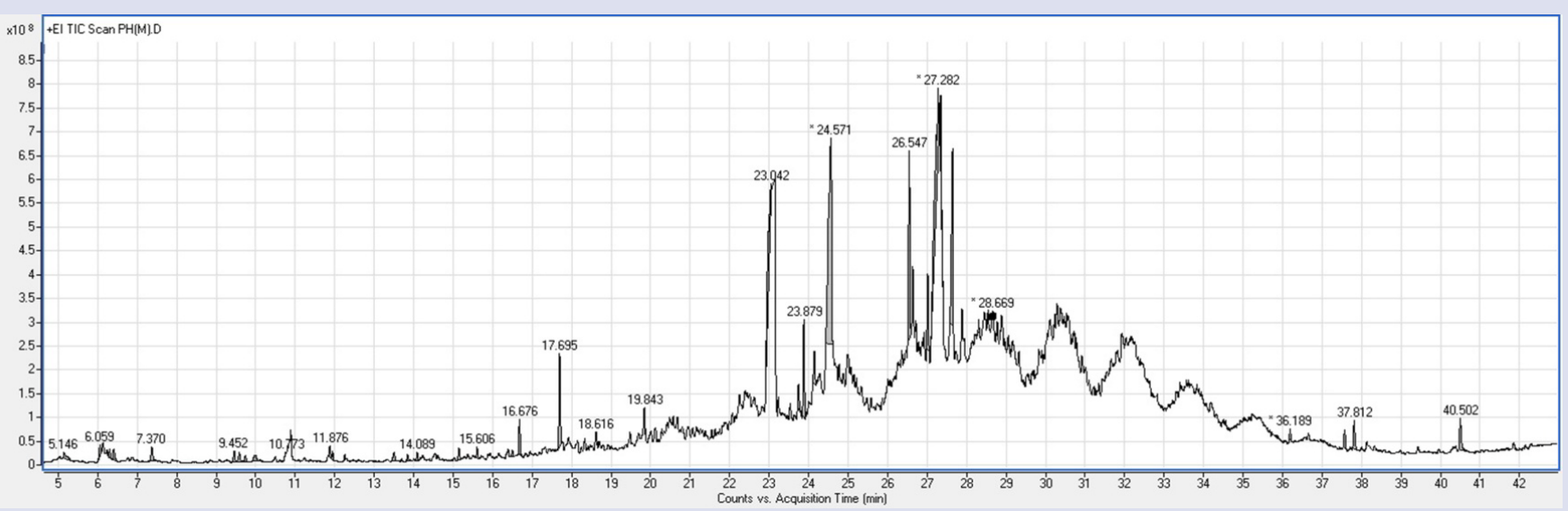

Figure 3: GC-MS chromatogram of Methanolextract of (MEP) of Phallus. 
Table 2: Major phytoconstituents identified in EAP extract of Phallus sp. and its biological uses.

\begin{tabular}{|c|c|c|c|c|c|c|c|c|}
\hline SI No. & RT & Area & Name of the compound & $\begin{array}{c}\text { Molecular } \\
\text { weight }\end{array}$ & $\begin{array}{l}\text { Molecular } \\
\text { formula }\end{array}$ & CAS \# & Biological Activity & Reference \\
\hline 1 & 37.58 & 8.61 & $\begin{array}{l}\text { Ergosta-5,22-dien-3- } \\
\quad \text { ol, }(3 \beta, 22 \mathrm{E}, 24 \mathrm{~S})\end{array}$ & 398 & $\mathrm{C}_{28} \mathrm{H}_{46} \mathrm{O}$ & $17472-78-5$ & anticancer & 41 \\
\hline 2 & 27.27 & 6.76 & 9,12-octadecadienoic acid $(\mathrm{Z}, \mathrm{Z})$ & 280 & $\mathrm{C}_{18} \mathrm{H}_{32} \mathrm{O}_{2}$ & $60-33-3$ & $\begin{array}{l}\text { antiinflammatory and } \\
\text { antiarthritic }\end{array}$ & 42 \\
\hline 3 & 44.20 & 4.03 & $\begin{array}{l}\text { Benzenepropanoic acid, } \\
\text { 3,5-bis(1,1-dimethylethyl)4- } \\
\text { hydroxy-,octadecyl ester }\end{array}$ & 530 & $\mathrm{C}_{35} \mathrm{H}_{62} \mathrm{O}_{3}$ & $2082-79-3$ & & \\
\hline 4 & 26.52 & 3.33 & $\begin{array}{l}\text { 9,12-octadecadienoic acid (Z,Z)- } \\
\text { methyl ester }\end{array}$ & 294 & $\mathrm{C}_{19} \mathrm{H}_{34} \mathrm{O}_{2}$ & $112-63-0$ & anticancer & 43 \\
\hline 5 & 32.82 & 3.30 & Di-n-octyl-phthalate & 390 & $\mathrm{C}_{24} \mathrm{H}_{38} \mathrm{O}_{4}$ & $117-84-0$ & & \\
\hline 6 & 25.00 & 3.27 & Chlorpyrifos & 349 & $\mathrm{C}_{9} \mathrm{H}_{11} \mathrm{Cl}_{3} \mathrm{NO}_{3} \mathrm{PS}$ & $2921-88-2$ & insecticides & 44 \\
\hline 7 & 19.84 & 2.80 & Dodecyl acrylate & 240 & $\mathrm{C}_{15} \mathrm{H}_{28} \mathrm{O}_{2}$ & $2156-97-0$ & antifungal & 45 \\
\hline 8 & 9.56 & 2.70 & Isopulegol & 154 & $\mathrm{C}_{10} \mathrm{H}_{18} \mathrm{O}$ & $89-79-2$ & antifungal & 46 \\
\hline 9 & 6.15 & 2.43 & D-limonene & 136 & $\mathrm{C}_{10} \mathrm{H}_{16}$ & $5989-27-5$ & anticancer & 47 \\
\hline 10 & 7.38 & 2.18 & $\begin{array}{c}\text { Bezene, } \\
\text { (1-methylenepropyl) }\end{array}$ & 132 & $\mathrm{C}_{10} \mathrm{H}_{12}$ & 2039-93-2 & & \\
\hline 11 & 37.82 & 2.16 & $\begin{array}{c}\text { Ergosta-5,7,9(11),22-tetraen-3-ol, } \\
(3 \beta, 22 \mathrm{E})\end{array}$ & 394 & $\mathrm{C}_{28} \mathrm{H}_{42} \mathrm{O}$ & $516-85-8$ & & \\
\hline 12 & 24.15 & 2.14 & Palmitoleic acid & 254 & $\mathrm{C}_{16} \mathrm{H}_{30} \mathrm{O}_{2}$ & $373-49-9$ & antiinflammatory & 48 \\
\hline 13 & 23.86 & 2.00 & Hexadecanoic acid, methyl ester & 270 & $\mathrm{C}_{17} \mathrm{H}_{34} \mathrm{O}_{2}$ & $112-39-0$ & antibacterial and antifungal & 4950 \\
\hline 14 & 16.39 & 1.95 & 2,4-Di-tert-butylphenol & 206 & $\mathrm{C}_{14} \mathrm{H}_{22} \mathrm{O}$ & $96-76-4$ & $\begin{array}{l}\text { antimicrobial, antifungal, } \\
\text { antioxidant, antitumor }\end{array}$ & 515253 \\
\hline 15 & 26.03 & 1.90 & $\begin{array}{l}\text { 2(1H)-Naphthalenone,octahydro- } \\
\text { 4a-phenyl-,trans }\end{array}$ & 228 & $\mathrm{C}_{16} \mathrm{H}_{20} \mathrm{O}$ & $22844-36-6$ & antimicrobial & 54 \\
\hline 16 & 27.85 & 1.75 & $\begin{array}{c}\text { Acetamide,N-[2-(1H-indol-3-yl }) \\
\text { ethyl]- }\end{array}$ & 202 & $\mathrm{C}_{12} \mathrm{H}_{14} \mathrm{~N}_{2} \mathrm{O}$ & $1016-47-3$ & & \\
\hline 17 & 41.86 & 1.71 & Ergosta-7,22-dien-3-ol, $(3 \beta, 5 \alpha)$ & 440 & $\mathrm{C}_{30} \mathrm{H}_{48} \mathrm{O}_{2}$ & $1449-60-1$ & & \\
\hline 18 & 6.07 & 1.67 & 1,3,8-p-Menthatriene & 134 & $\mathrm{C}_{10} \mathrm{H}_{14}$ & $18368-95-1$ & aromatic volatile compound & 55 \\
\hline 19 & 26.61 & 1.54 & $\begin{array}{l}\text { 9-Octadecenoic acid(Z)-,methyl } \\
\text { ester }\end{array}$ & 296 & $\mathrm{C}_{19} \mathrm{H}_{36} \mathrm{O}_{2}$ & $112-62-9$ & anticancer & 4350 \\
\hline 20 & 24.49 & 1.31 & n-Hexadecanoic acid & 256 & $\mathrm{C}_{16} \mathrm{H}_{32} \mathrm{O}_{2}$ & $57-10-3$ & $\begin{array}{l}\text { antiinflammatoy, } \\
\text { antioxidant, } \\
\text { hemolytic, } \\
\text { 5-Alpha reductase } \\
\text { inhibitor. }\end{array}$ & 5657 \\
\hline 21 & 29.17 & 1.24 & $\begin{array}{c}\text { (4-Isopropylidenebicyclo[3.2.0] } \\
\text { hept-2-en-6-ylidene)acetic } \\
\text { acid,methyl ester }\end{array}$ & 204 & $\mathrm{C}_{13} \mathrm{H}_{16} \mathrm{O}_{2}$ & & & \\
\hline 22 & 36.65 & 1.22 & $\begin{array}{l}\text { 3a-5-cyclo 5a-ergosta-6,8(14).22t- } \\
\text { triene }\end{array}$ & 378 & $\mathrm{C}_{28} \mathrm{H}_{42}$ & $24352-51-0$ & & \\
\hline 23 & 21.62 & 1.19 & 1-Nonadecene & 266 & $\mathrm{C}_{19} \mathrm{H}_{38}$ & $18435-45-5$ & $\begin{array}{l}\text { antimicrobial, antioxidant } \\
\text { and anticancer }\end{array}$ & 58 \\
\hline 24 & 9.45 & 1.13 & 1H-Indene,1-methylene & 128 & $\mathrm{C}_{10} \mathrm{H}_{8}$ & $2471-84-3$ & & \\
\hline 25 & 14.54 & 1.11 & Naphthalene,1,7-dimethyl- & 156 & $\mathrm{C}_{12} \mathrm{H}_{12}$ & $575-37-1$ & & \\
\hline 26 & 22.25 & 1.10 & Benzene,(1-pentyloctyl)- & 260 & $\mathrm{C}_{19} \mathrm{H}_{22}$ & $4534-49-0$ & & \\
\hline 27 & 21.81 & 1.08 & $\begin{array}{c}\text { 2,8-Decadienedioic acid,diethyl } \\
\text { ester }\end{array}$ & 254 & $\mathrm{C}_{14} \mathrm{H}_{22} \mathrm{O}_{4}$ & $4921-68-0$ & antibacterial & 59 \\
\hline 28 & 10.76 & 1.07 & 1-Phenoxypropan-2-ol & 154 & $\mathrm{C}_{9} \mathrm{H}_{12} \mathrm{O}_{2}$ & $770-35-4$ & & \\
\hline 29 & 27.34 & 1.04 & Oleic acid & 282 & $\mathrm{C}_{18} \mathrm{H}_{34} \mathrm{O}_{2}$ & $112-80-1$ & antibacterial & 60 \\
\hline
\end{tabular}

which appeared at 37.58 and 27.27 minutes interval with $8.61 \%$ and $6.78 \%$ peak area respectively. There were also many minor compounds such as bnzenepropanoic acid, 3,5-bis (1,1-dimethylethyl)4-hydroxy,octadecyl ester (4.03\%), Di-n-octyl-phthalate (3.30\%), Chlorpyrifos (3.27\%), Isopulegol (2.70\%), D-limonene (2.43\%) etc. traced in EAP extract. n-Hexadecanoic acid (23.34\%) and 9,12-Octadecadienoic acid $(\mathrm{Z}, \mathrm{Z})$ (12.23\%) were found as a major compound in MEP extract and were appeared at 24.571 and 27.282 minutes time interval respectively. Several minor compound such as Octadecadienoic acid (9.72\%); 9,12-Octadecadienoic acid (Z,Z) methyl ester (9.52\%); 1,4-Benzenedicarboxylic acid, bis (2-methylpropyl) ester
(7.14\%); hexadecanoic acid, methyl ester (4.64\%); aromadendrene (4.54\%) were also detected from MEP extract. Nine compounds namely n-Hexadecanoic acid; 9,12-Octadecadienoic acid(Z,Z); 9,12-Octadecadienoic acid (Z,Z) methyl ester; hexadecanoic acid, methyl ester; oleic acid, 9-Octadecadienoic acid (Z) methyl ester; ergosta-5,7,9(11)22-tetraen-3-ol(3 $\beta, 22 E)$-; $\quad 9,12$-Octadecadienoic acid $(Z, Z)$ were shared by both of the MEP and EAP. It was clearly observed that most of the fatty acid and its methylated derivatives are common for both of the extracts. Reported biological activities of the detected compounds were also listed in the Table 2 and Table 3 respectively. 
Table 3: Major phytoconstituents identified in MEP extracts of Phallus sp. and its biological uses.

\begin{tabular}{|c|c|c|c|c|c|c|c|c|}
\hline SI No & RT & Area & Name of the compound & Molecular weight & Molecular formula & CAS \# & Biological Activity & Reference \\
\hline 1 & 24.571 & 23.34 & n-Hexadecanoic acid & 256 & $\mathrm{C}_{16} \mathrm{H}_{32} \mathrm{O}_{2}$ & $57-10-3$ & $\begin{array}{l}\text { antiinflammatoy, } \\
\text { antioxidant, } \\
\text { hemolytic, } \\
\text { 5-Alpha reductase } \\
\text { inhibitor. }\end{array}$ & 5657 \\
\hline 2 & 27.282 & 12.23 & $\begin{array}{c}\text { 9,12-Octadecadienoic } \\
\operatorname{acid}(\mathrm{Z}, \mathrm{Z})\end{array}$ & 280 & $\mathrm{C}_{18} \mathrm{H}_{32} \mathrm{O}_{2}$ & $60-33-3$ & antiinflammatory and antiarthritic & 42 \\
\hline 3 & 27.646 & 9.72 & Octadecadienoic acid & 284 & $\mathrm{C}_{18} \mathrm{H}_{36} \mathrm{O}_{2}$ & $57-11-4$ & & \\
\hline 4 & 26.547 & 9.52 & $\begin{array}{l}\text { 9,12-Octadecadienoic } \\
\text { acid }(\mathrm{Z}, \mathrm{Z}) \text { methyl ester }\end{array}$ & 294 & $\mathrm{C}_{19} \mathrm{H}_{34} \mathrm{O}_{2}$ & $112-63-0$ & anticancer & 43 \\
\hline 5 & 23.042 & 7.14 & $\begin{array}{c}\text { 1,4-Benzenedicarboxylic } \\
\text { acid, bis(2-methylpropyl) } \\
\text { ester }\end{array}$ & 278 & $\mathrm{C}_{16} \mathrm{H}_{22} \mathrm{O}_{4}$ & $18699-48-4$ & & \\
\hline 6 & 23.879 & 4.64 & $\begin{array}{l}\text { Hexadecanoic acid, } \\
\text { methyl ester }\end{array}$ & 270 & $\mathrm{C}_{17} \mathrm{H}_{34} \mathrm{O}_{2}$ & $112-39-0$ & antibacterial and antifungal & 4950 \\
\hline 7 & 17.695 & 4.54 & Aromadendrene, dihydro & 202 & $\mathrm{C}_{15} \mathrm{H}_{22}$ & & anticancer & 61 \\
\hline 8 & 27.344 & 3.16 & Oleic Acid & 282 & $\mathrm{C}_{18} \mathrm{H}_{34} \mathrm{O}_{2}$ & $112-80-1$ & antibacterial & 60 \\
\hline 9 & 27.017 & 3.06 & Methyl stearate & 298 & $\mathrm{C}_{19} \mathrm{H}_{38} \mathrm{O}_{2}$ & $112-61-8$ & anticancer & 62 \\
\hline 10 & 40.502 & 1.97 & $\begin{array}{c}\text { Ergosta-7,22-dien-3-ol, } \\
(3 \beta, 5 \alpha, 22 \mathrm{E})-\end{array}$ & 398 & $\mathrm{C}_{28} \mathrm{H}_{46} \mathrm{O}$ & $2465-11-4$ & & \\
\hline 11 & 26.638 & 1.78 & $\begin{array}{l}\text { 9-Octadecadienoic acid } \\
\text { (,Z) methyl ester }\end{array}$ & 296 & $\mathrm{C}_{19} \mathrm{H}_{36} \mathrm{O}_{2}$ & $112-62-9$ & anticancer & 4350 \\
\hline 12 & 16.676 & 1.70 & Aromadendrene,dehydro- & 202 & $\mathrm{C}_{15} \mathrm{H}_{22}$ & & anticancer & 61 \\
\hline 13 & 37.812 & 1.54 & $\begin{array}{l}\text { Ergosta-5,7,9(11)22- } \\
\text { tetraen-3-ol, }(3 \beta, 22 \mathrm{E}) \text { - }\end{array}$ & 394 & $\mathrm{C}_{28} \mathrm{H}_{42} \mathrm{O}$ & $516-85-8$ & & \\
\hline 14 & 24.134 & 1.27 & Hexadecanoicacid,Z-11- & 254 & $\mathrm{C}_{16} \mathrm{H}_{30} \mathrm{O}_{2}$ & $2416-20-8$ & & \\
\hline 15 & 23.745 & 1.12 & Dibutyl phthalate & 278 & $\mathrm{C}_{16} \mathrm{H}_{22} \mathrm{O}_{4}$ & $84-74-2$ & antibacterial & 63 \\
\hline 16 & 27.883 & 1.07 & $\begin{array}{c}\text { 9,12-Octadecadienoic } \\
\text { acid }(\mathrm{Z}, \mathrm{Z})\end{array}$ & 280 & $\mathrm{C}_{18} \mathrm{H}_{32} \mathrm{O}_{2}$ & $60-33-3$ & anticancer & 62 \\
\hline
\end{tabular}

\section{Evaluation of antioxidant potential of MEP}

\section{DPPH free radical scavenging Assay}

DPPH free radical scavenging assay was carried out with different concentration range $(100-500 \mu \mathrm{g} / \mathrm{mL}$ ) of the MEP extract (Figure $4 \mathrm{~A}$ ). Result indicated that with increase of the mushroom concentration the percentage of scavenging of DPPH radical proportionally increase in a linear manner. The percentage of scavenging of DPPH radical increase $10.073 \pm 0.8250 \%$ to $61.276 \pm 8.286 \%$ at concentration range $100 \mu \mathrm{g} / \mathrm{mL}$ to $500 \mu \mathrm{g} / \mathrm{mL}$ (Table 4). The $\mathrm{IC}_{50}$ value is the particular concentration at which $50 \%$ of free radical is scavenged by antioxidant molecule of the extract ${ }^{5}$. The $\mathrm{IC}_{50}$ value of MEP against the $\mathrm{DPPH}^{+}$free radical was $426.723 \pm 17.574 \mu \mathrm{g} / \mathrm{mL}$ (Table 5).

\section{ABTS•+ free radical scavenging assay}

free radical scavenging assay was also performed same concentration range $(100-500 \mu \mathrm{g} / \mathrm{mL})$ of the MEP extract (Figure $4 \mathrm{~A})$. The percentage of scavenging of ABTS $\bullet+$ free radical proportionally increased with the concentration of MEP extract of mushroom in a linear manner (Figure 4). The percentage of scavenging of ABTS $\bullet+$ free radical increase $27.295 \pm 1.974 \%$ to $91.790 \pm 2.277 \%$ at concentration range $100 \mu \mathrm{g} / \mathrm{mL}$ to $500 \mu \mathrm{g} / \mathrm{mL}$ (Table 4). The IC $\mathrm{I}_{50}$ value of MEP against the ABTS •+ free radical was $209.671 \pm 6.314 \mu \mathrm{g} / \mathrm{mL}$ (Table 5).

This result indicated that antioxidant molecule present in MEP extract of Phallus was more effective on ABTS • + free radical than DPPH free radical (Table 5).

\section{Assessment of antioxidant compound present in MEP}

\section{Total phenol content}

Total phenol content of MEP of Phallus sp. was expressed as Gallic acid equivalent of phenol par gram of mushroom dry weight. Different concentration of Gallic acid $(0-10 \mu \mathrm{g} / \mathrm{mL})$ was used as equivalent standard and finally the equivalent concentration of total phenol content of MEP was determined from the equation $\mathrm{y}=0.138 \mathrm{x}+0.062, \mathrm{R}^{2}=0.996 \quad \mathrm{x}=$ gallic acid concentration, $\mathrm{y}=$ absorbance of MEP). The MEP contented $6.771 \pm 0.031 \mathrm{mg}$ Gallic acid equivalent of phenol content present par gram of mushroom dry weight Table 6 (Figure 4B).

\section{Total flavonoid content determination}

The total flavonoid content of MEP of this mushroom were expressed as Quercetin equivalent of flavonoid per gram of mushroom dry weight. Quercetin (concentration range $0-100 \mu \mathrm{g} / \mathrm{mL}$ ) was used as equivalent standard and equivalent concentration of total flavonoid content of MEP was determined from the equation $y=0.008 x+0.012$, $\mathrm{R}^{2}=0.976(\mathrm{x}=$ Quercetin concentration, $\mathrm{y}=$ absorbance of MEP $)$. The MEP contented $32.628 \pm 0.082 \mathrm{mg}$ Quercetin equivalent of flavonoid per gram of mushroom dry weight Table 6 (Figure 4B).

The major antioxidant compound present in the MEP extract was flavonoid molecules. The total flavonoid content of the MEP was higher than phenol content. 
Table 4: Comparative analysis of the free radical scavenging potentiality of different concentration (100-500 $\mathrm{\mu g} / \mathrm{mL}$ ) of MEP extract on DPPH and ABTS - free radical. Results are the mean value of two independent experiments with standard deviation.

\begin{tabular}{ccc}
\hline MEP $(\mu \mathrm{g} / \mathrm{mL})$ & (\%) DPPH free radical & (\%) ABTS + free radical \\
\hline 100 & $10.073 \pm 0.825$ & $27.294 \pm 1.973$ \\
200 & $20.674 \pm 0.904$ & $50.893 \pm 3.993$ \\
300 & $33.395 \pm 0.999$ & $69.085 \pm 6.993$ \\
400 & $44.979 \pm 3.960$ & $84.145 \pm 0.813$ \\
500 & $61.276 \pm 8.285$ & $91.790 \pm 2.276$ \\
\hline
\end{tabular}

Table 5: Comparative analysis of $\mathrm{IC}_{50}(\mu \mathrm{g} / \mathrm{mL})$ values of MEP of Phallus sp. on DPPH and $A B T S \cdot+f r e e$ radical. Results are the mean value of two independent experiments with standard deviation.

\begin{tabular}{ccc}
\hline & DPPH free radical $(\mu \mathrm{g} / \mathrm{mL})$ & ABTS॰ free radical $(\mu \mathrm{g} / \mathrm{mL})$ \\
\hline $\mathrm{IC}_{50}$ of MEP & $426.723 \pm 17.574$ & $209.671 \pm 6.314$ \\
\hline
\end{tabular}

Table 6: Comparative analysis of antioxidant compound profile of MEP of Phallus sp. Results are the mean value of two independent experiments with standard deviation.

\begin{tabular}{cc}
\hline $\begin{array}{c}\text { Total Phenol Content } \\
\text { (mg Gallic acid equivalent / gram of dry weight) }\end{array}$ & $\begin{array}{c}\text { Total Flavonoid Content } \\
\text { (mg Quercetin equivalent / gram of dry weight) }\end{array}$ \\
\hline $6.771 \pm 0.031$ & $32.628 \pm 0.082$ \\
\hline
\end{tabular}

a)

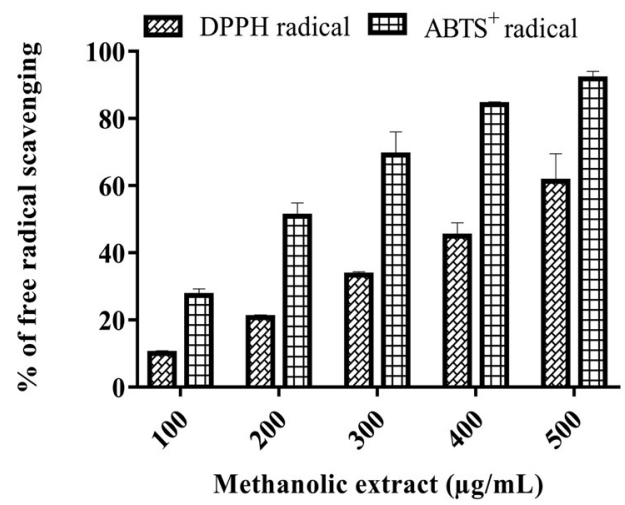

b)

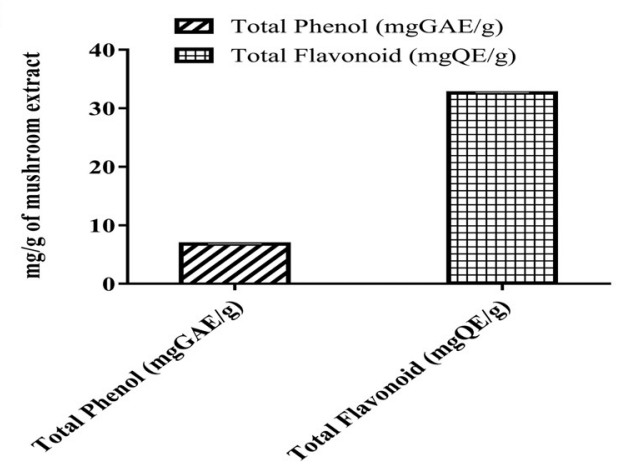

Figure 4: Evaluation of antioxidant potential of MEP and assessment of antioxidant compound A) Comparative study of DPPH and ABTS + free radical scavenging potential of MEP B) Comparative study of total phenol and flavonoid content of MEP.

\section{DISCUSSION}

Both MEP and EAP extracts showed very appreciable anti-proliferative activity with $\mathrm{IC}_{50}$ value against MCF-7 $8.54 \pm 2.81 \mu \mathrm{g} / \mathrm{mL} \quad 35.27 \pm 2.86$ $\mu \mathrm{g} / \mathrm{mL}$ respectively and negligible effect on normal PBMCs. Moderate activity of MEP and EAP on REH cell line and almost no antiproliferative effect were observed. Data taken together indicates the effectiveness of Phallus extract specifically on breast cancer. Different derivatives of ergosterol such as Ergosta-5,22-dien-3-ol,(3ß,22E,24S);Ergosta-5,7,9(11),22-tetraen-3-ol, $\quad(3 \beta, 22 \mathrm{E})$;Ergosta-7,22-dien-3-ol,

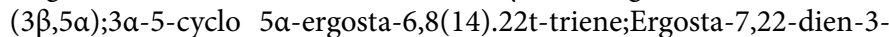

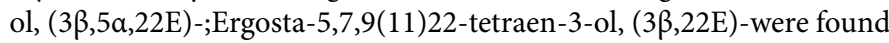
on both of EAP and MEP extracts of this mushroom. Previous authors reported that ergosterol extracted from Amauroderma rude was very effective against human breast cancer cells MDA-MB-231, it upregulated expression of Foxo-3 which further down regulate several down-stream signaling molecules like Fas, FasL, BimL, and BimS thus further enhance apoptotic stimuli ${ }^{64}$. This observation also supports our findings. As GC data clearly indicate that MEP extract of the Phallus contained Ergosta-7,22-dien-3-ol, $(3 \beta, 5 \alpha, 22 \mathrm{E})-(1.97 \%)$ and Ergosta5,7,9(11)22-tetraen-3-ol (1.54\%) which probably responsible molecule for its high anti-proliferation activity. Several ergosterol derivatives of were also traced from EAP extract of Phallus. Probably ergosterol derivativs present in MEP extract was more potent than EAP extract with respect to its anticancer property.

Different sets of bioactive compounds were also found in both EAP and MEP extracts with various bioactive properties such as anti-bacterial, anti-fungal, anti-inflammatory, anti-diabetic etc. Among several conventional cancer treatments, chemotherapy is most frequently carried out to treat malignant cancer. Most of the chemotherapeutic drugs show a plethora of side effects. The most of the commonly used anticancer drugs, especially designed for targeting DNA molecule are associated with various adverse reactions such as excessive production of reactive oxygen species (ROS) and subsequent build up of oxidative stress. To allay these undesired side effects, antioxidants are used as an adjuvant in chemotherapy ${ }^{65}$. As the MEP extract of the Phallus sp. had shown very potent anticancer activity, the antioxidant potentiality of MEP was also evaluated.

Flavonoid and phenolic compounds are large groups of naturally occurring polyphenol compounds which depict the antioxidant profile 
of any biological mixtures. The MEP showed higher flavonoid content than phenol content. MEP also showed moderate antioxidant activity and very prominent impact on ABTS •+ free radical. So, MEP extract of Phallus may be selected as future safe alternative anticancer drug and potent antioxidant adjuvant for chemotherapy. So, MEP extract of Phallus sp. can be tapped to isolate and purify novel anticancer compound in future for development of anticancer drug and antioxidant adjuvant for chemotherapy.

\section{CONCLUSION}

This wild mushroom Phallus sp. showed very promising antiproliferative activity on human breast cancer cell line MCF-7 followed by REH. Both extracts showed its effect specifically towards the cancer cells, irrespective of normal PBMC cells. ROS is generated due to oxidative stress, is very harmful for living system. Our study showed that methanolic extracts was very potent for quenching of the free radicals. Our study also showed that methanolic extract of this wild stinkhorn is very potent candidate for not only as a safe alternative anticancer drug but also an effective chemotherapeutic antioxidant adjuvant. Presence of various anticancer and antioxidant molecule were detected from GC-MS analysis, which also supports above conclusion. Different derivatives of ergosterol may be probable anticancer molecules. So, it can be concluded that the methanolic extract of this wild stinkhorn can be tapped to isolate and purify potent anticancer compound in future.

\section{ACKNOWLEDGEMENT}

The authors are thankful to UGC-CAS programme at the Department of Botany, University of Calcutta for financial support. Authors also acknowledge IISER Kolkata for instrumental support.

\section{CONFLICTS OF INTEREST}

The authors report no conflict of interest.

\section{AUTHOR CONTRIBUTION}

Entire design of the experimental work was done by Prof. Santanu Paul. Amrita Pal and Ribhu Ray collected this mushroom. Molecular identification, extract preparation, phytochemical profiling study and antioxidant profiling was carried out by Ribhu Ray. Amrita Pal performed the cell viability assay. Prof. Santanu Paul and Ribhu Ray analysed data and wrote the manuscript. All authors approved the final manuscript.

\section{REFERENCES}

1. Bray F, Ferlay J, Soerjomataram I, Siegel RL, Torre LA, Jemal A. Global cancer statistics 2018: GLOBOCAN estimates of incidence and mortality worldwide for 36 cancers in 185 countries. CA Cancer J Clin. 2018;68(6):394-424. doi:10.3322/caac. 21492

2. Ferlay J, Colombet M, Soerjomataram I, et al. Estimating the global cancer incidence and mortality in 2018: GLOBOCAN sources and methods. Int J Cancer. 2019;144(8):1941-1953. doi:10.1002/ijc.31937

3. Siegel RL, Miller KD, Jemal A. Cancer statistics, 2020. CA Cancer J Clin. 2020;70(1):7-30. doi:10.3322/caac.21590

4. Smith RD, Mallath MK. of the Growing Burden of Cancer in India: From Antiquity to the 21Historyst Century. J Glob Oncol. 2019;(5):1-15. doi:10.1200/ JGO.19.00048

5. Pal A, Chouni A, Das A, Ray R, Paul S. Evaluation of Anti-proliferative Potential and Antioxidant Activity of a Wild Edible Mushroom Macrocybe crassa (Sacc.) Pegler and Lodge. Pharmacogn J. 2019;11(6s):1504-1510.

6. Das SK, Ladusingh L. Why is the inpatient cost of dying increasing in India? PLoS One. 2018;13(9):e0203454. https://doi.org/10.1371/journal.pone.0203454.

7. Kastor A, Mohanty SK. Disease-specific out-of-pocket and catastrophic health expenditure on hospitalization in India: Do Indian households face distress health financing? PLoS One. 2018;13(5):e0196106-e0196106. doi:10.1371/ journal.pone.0196106

8. Rajpal S, Kumar A, Joe W. Economic burden of cancer in India: Evidence from cross-sectional nationally representative household survey, 2014. PLoS One. 2018;13(2):e0193320-e0193320. doi:10.1371/journal.pone.0193320
9. Begg AC, Stewart FA, Vens C. Strategies to improve radiotherapy with targeted drugs. Nat Rev Cancer. 2011;11(4):239-253. doi:10.1038/nrc3007

10. Chen $X$. Protection of Normal Proliferating Cells Against Chemotherapy by Staurosporine-Mediated, Selective, and Reversible G1 Arrest. J Natl Cancer Inst. 2000;92(24):1999-2008. doi:10.1093/jnci/92.24.1999

11. Cheok CF. Protecting normal cells from the cytotoxicity of chemotherapy. Cell Cycle. 2012;11(12):2227-2228. doi:10.4161/cc.20961

12. Parida PK, Mahata B, Santra A, et al. Inhibition of cancer progression by a novel trans-stilbene derivative through disruption of microtubule dynamics, driving G2/M arrest, and p53-dependent apoptosis. Cell Death Dis. 2018;9(5). doi:10.1038/s41419-018-0476-2

13. Gassecka M, Mleczek M, Siwulski M, Niedzielski P. Phenolic composition and antioxidant properties of Pleurotus ostreatus and Pleurotus eryngi enriched with selenium and zinc. Eur Food Res Technol. 2016;242(5):723-732. doi:10.1007/s00217-015-2580-1

14. Patel S, Goyal A. Recent developments in mushrooms as anti-cancer therapeutics: a review. 3 Biotech. 2012;2(1):1-15. doi:10.1007/s13205-011-00362

15. Barros L, Baptista P, Estevinho LM, Ferreira ICFR. Bioactive properties of the medicinal mushroom Leucopaxillus giganteus mycelium obtained in the presence of different nitrogen sources. Food Chem. 2007;105(1):179-186. doi:10.1016/j.foodchem.2007.03.063

16. Sarikurkcu C, Tepe B, Yamac M. Evaluation of the antioxidant activity of four edible mushrooms from the Central Anatolia, Eskisehir - Turkey: Lactarius deterrimus, Suillus collitinus, Boletus edulis, Xerocomus chrysenteron. Bioresour Technol. 2008;99(14):6651-6655. doi:10.1016/j.biortech.2007.11.062

17. Wang Z, Luo D, Liang Z. Structure of polysaccharides from the fruiting body of Hericium erinaceus Pers. Carbohydr Polym. 2004;57(3):241-247. doi:10.1016/j. carbpol.2004.04.018

18. Kim HG, Yoon $\mathrm{DH}$, Lee $\mathrm{WH}$, et al. Phellinus linteus inhibits inflammatory mediators by suppressing redox-based NF- $\kappa$ B and MAPKs activation in lipopolysaccharide-induced RAW 264.7 macrophage. J Ethnopharmacol. 2007;114(3):307-315. doi:10.1016/j.jep.2007.08.011

19. Synytsya A, Míčková K, Synytsya A, et al. Glucans from fruit bodies of cultivated mushrooms Pleurotus ostreatus and Pleurotus eryngii: Structure and potential prebiotic activity. Carbohydr Polym. 2009;76(4):548-556. doi:10.1016/j. carbpol.2008.11.021

20. Gogoi G, Parkash V. Some New Records of Stinkhorns (Phallaceae) from Hollongapar Gibbon Wildlife Sanctuary, Assam, India. J Mycol. 2014;2014(Figure 1):1-8. doi:10.1155/2014/490847

21. Tuno N. Spore dispersal of Dictyophora fungi (Phallaceae) by flies. Ecol Res. 1998;13(1):7-15. doi:10.1046/j.1440-1703.1998.00241.x

22. Li H, Mortimer PE, Karunarathna SC, Xu J, Hyde KD. New species of Phallus from a subtropical forest in Xishuangbanna, China. Phytotaxa. 2014;163(2):91103. doi:10.11646/phytotaxa.163.2.3

23. Li H, MaX, Mortimer PE, Karunarathna SC, Xu J, Hyde KD. Phallus haitangensis, a new species of stinkhorn from Yunnan province, China. Phytotaxa. 2016;280(2):116-128. doi:10.11646/phytotaxa.280.2.2

24. Desjardin DE, Perry BA. A new species of Phallus from São Tomé, Africa. Mycologia. 2009;101(4):545-547. doi:10.3852/08-166

25. Hemmes DE, Desjardin DE. Haw aiian IsI ands. 2009;2(January 2009):8-10.

26. Dash PK, Sahu DK, Sahoo S, Das R. Phallus indusiatus Vent. \& Pers. (Basidiomycetes) - a new generic record for Eastern Ghats of India. J Threat Taxa. 2010;2(8):1096-1098. doi:10.11609/jott.02305.1096-8

27. Sridhar KR, Karun NC. On the Basket Stinkhorn Mushroom Phallus merulinus (Phallaceae) in Mangalore, Karnataka, India. J Threat Taxa. 2013;5(5):3985-3988. doi:10.11609/jott.03312.3985-8

28. Kour H, Yangdol R, Kumar S, SharmaYP.Three species of Phallus (Basidiomycota: Agaricomycetes: Phallaceae) from Jammu \& Kashmir, India. J Threat Taxa. 2016;8(1):8403-8409. doi:10.11609/jott.2173.8.1.8403-8409

29. White TJ, Bruns T, Lee S, Taylor J. AMPLIFICATION AND DIRECT SEQUENCING OF FUNGAL RIBOSOMAL RNA GENES FOR PHYLOGENETICS. PCR Protoc. January 1990:315-322. doi:10.1016/B978-0-12-372180-8.50042-1

30. Gopal PK, Paul M, Paul S. Curcumin induces caspase mediated apoptosis in JURKAT cells by disrupting the redox balance. Asian Pacific J Cancer Prev. 2014;15(1):93-100. doi:10.7314/APJCP.2014.15.1.93

31. Sujarwo W, Keim AP. Chapter 27 - Spondias pinnata (L. f.) Kurz. (Anacardiaceae) Profiles and Applications to Diabetes. In: Watson RR, Preedy VRBT-BF as DI for D (Second E, eds. Academic Press; 2019:395-405. doi:https://doi.org/10.1016/ B978-0-12-813822-9.00027-8

32. Hajra D, Paul S. Study of glucose uptake enhancing potential of fenugreek (Trigonella foenum graecum) leaves extract on 3T3 $\mathrm{L} 1$ cells line and evaluation of its antioxidant potential. Pharmacognosy Res. 2018;10(4):347-353. doi:10.4103/ pr.pr_50_18 
33. Brand-Williams W Cuvelier ME Berset C Use of a free radical method to evaluate antioxidant activity. LWT - Food Sci Technol. 1995;28(1):25-30. doi:https://doi.org/10.1016/S0023-6438(95)80008-5

34. Re R, Pellegrini N, Proteggente A, Pannala A, Yang M, Rice-Evans C. Antioxidant activity applying an improved ABTS radical cation decolorization assay. Free Radic Biol Med. 1999;26(9):1231-1237. doi:https://doi.org/10.1016/S08915849(98)00315-3

35. Singleton VL, Orthofer R, Lamuela-Raventós RMBT-M in E. [14] Analysis of total phenols and other oxidation substrates and antioxidants by means of folin-ciocalteu reagent. In: Oxidants and Antioxidants Part A. Vol 299. Academic Press; 1999:152-178. doi:https://doi.org/10.1016/S0076-6879(99)99017-1

36. Mridha A, Nandi C, Pal R, Paul S. Studies on few fresh water green algal species reveals Spirogyra triplicata as the repository of high phenolic and flavonoid content exhibiting enhanced anti-oxidant property. $1291 \sim$ J Pharmacogn Phytochem. 2017;6(4):1291-1297.

37. Singh V, Guizani N, Essa MM, Hakkim FL, Rahman MS. Comparative analysis of total phenolics, flavonoid content and antioxidant profile of different date varieties (Phoenix dactylifera L.) From Sultanate of Oman. Int Food Res J. 2012;19(3):1063-1070.

38. Gismondi A, Fanali F, Martínez Labarga JM, Caiola MG, Canini A. Crocus sativus L. Genomics and different DNA barcode applications. Plant Syst Evol. 2013;299(10):1859-1863. doi:10.1007/s00606-013-0841-7

39. Dentinger BTM, Didukh MY, Moncalvo J-M. Comparing COI and ITS as DNA Barcode Markers for Mushrooms and Allies (Agaricomycotina). PLoS One. $2011 ; 6(9):$ e25081. https://doi.org/10.1371/journal.pone.0025081.

40. Khatua S, Acharya K. Influence of extraction parameters on physicochemical characters and antioxidant activity of water soluble polysaccharides from Macrocybe gigantea (Massee) Pegler \& Lodge. J Food Sci Technol. 2016;53(4):1878-1888. doi:10.1007/s13197-015-2145-0

41. Byju K, Anuradha V, Vasundhara G, Nair SM, Kumar NC. In vitro and in silico studies on the anticancer and apoptosis-inducing activities of the sterols identified from the soft coral, subergorgia reticulata. Pharmacogn Mag. 2014;10(37):S65-S71. doi:10.4103/0973-1296.127345

42. Jones PJ. Functional foods - More than just nutrition. Cmaj. 2002;166(12):15551563.

43. Yu FR, Lian XZ, Guo HY, et al. Isolation and characterization of methyl esters and derivatives from Euphorbia kansui (Euphorbiaceae) and their inhibitory effects on the human SGC-7901 cells. J Pharm Pharm Sci. 2005;8(3):528-535.

44. Mai S, Ninga E, Cara M, Mukaj M. Determination of Chlorpyrifos Residues in Lettuce by GC MS/MS. Proc 4th GlobVirtual Conf. 2016:4:285-287. doi:10.18638/ gv.2016.4.1.762

45. Singh T, Wahla V. Gc-Ms Analysis of Antifungal Compounds Derived From Soil Actinobacteria. Int Res J Pharm. 2018;9(2):81-84. doi:10.7897/2230-8407.09232

46. Pan M, Lei Q, Zang N, Zhang H. A strategy based on GC-MS/MS, UPLC-MS/ MS and virtual molecular docking for analysis and prediction of bioactive compounds in Eucalyptus globulus leaves. Int J Mol Sci. 2019;20(16). doi:10.3390/ijms20163875

47. Vigushin DM, Poon GK, Boddy A, et al. Phase I and pharmacokinetic study of D-limonene in patients with advanced cancer. Cancer Chemother Pharmacol. 1998;42(2):111-117. doi:10.1007/s002800050793

48. Astudillo AM, Meana C, Guijas C, et al. Occurrence and biological activity of palmitoleic acid isomers in phagocytic cells. J Lipid Res. 2018;59(2):237-249. doi:10.1194/jIr.M079145

49. Chandrasekaran M, Senthilkumar A, Venkatesalu V. Antibacterial and antifungal efficacy of fatty acid methyl esters from the leaves of Sesuvium portulacastrum L. Eur Rev Med Pharmacol Sci. 2011;15(7):775-780.
50. Singh R, Chaturvedi P. Phytochemical Characterization of Rhizome, Fruit, Leaf and Callus of Rheum emodi Wall. using GC-MS. Pharmacogn J. 2019;11(3):617623. doi:10.5530/pj.2019.11.99

51. Yoon M-A, Jeong T-S, Park D-S, et al. Antioxidant Effects of Quinoline Alkaloids and 2,4-Di-tert-butylphenol Isolated from Scolopendra subspinipes. Biol Pharm Bull. 2006;29(4):735-739. doi:10.1248/bpb.29.735

52. Zhao F, Wang P, Lucardi RD, Su Z, Li S. Natural sources and bioactivities of 2,4-ditert-butylphenol and its analogs. Toxins (Basel). 2020;12(1):1-26. doi:10.3390/ toxins 12010035

53. Varsha KK, Devendra L, Shilpa G, Priya S, Pandey A, Nampoothiri KM. 2,4-Ditert-butyl phenol as the antifungal, antioxidant bioactive purified from a newly isolated Lactococcus sp. Int J Food Microbiol. 2015;211:44-50. doi:https://doi org/10.1016/j.ijfoodmicro.2015.06.025

54. Dinde AV, Lokhande PB, Mujawar HA. Essential Oil Extraction, Characterization and Anti microbial study of Cythocline purpurea from Konkan Region. 2017;11 (5).

55. Farouk A, Ali H, Al-Khalifa AR, Mohsen M, Fikry R. Aroma volatile compounds of parsley cultivated in the Kingdom of Saudi Arabia and Egypt extracted by hydrodistillation and headspace solid-phase microextraction. Int J Food Prop. 2018;20(3):S2868-S2877. doi:10.1080/10942912.2017.1381707

56. Vasudevan, Dileep K V., Mandal PK, Karthe P, Sadasivan C, Haridas, MadathilkovilakathAparna U. Anti-Inflammatory Property of n-Hexadecanoic Acid: Structural Evidence and Kinetic Assessment. Chem Biol Drug Des. 2012;80(3):434-439. doi:10.1111/j.1747-0285.2012.01418.x

57. Kumar PP, Kumaravel S, Lalitha C. African journal of biochemistry research. African J Biochem Res . 2010;4(7):191-195. http://www.academicjournals.org/ journal/AJBR/article-abstract/743A94611519.

58. Madkour HMF, Ghareeb MA, Abdel-Aziz MS, et al. Gas chromatography-mass spectrometry analysis, antimicrobial, anticancer and antioxidant activities of n-hexane and methylene chloride extracts of Senna italica. J Appl Pharm Sci. 2017;7(6):023-032. doi:10.7324/JAPS.2017.70604

59. Priyanka S, Jayashree M, Shivani R, Anwesha S, Bhaskara Rao K V, I AE. Characterisation and identification of antibacterial compound from marine actinobacteria: In vitro and in silico analysis. J Infect Public Health. 2019;12(1):8389. doi:https://doi.org/10.1016/j.jiph.2018.09.005

60. Dilika F, Bremner PD, Meyer JJM. Antibacterial activity of linoleic and oleic acids isolated from Helichrysum pedunculatum: a plant used during circumcision rites. Fitoterapia. 2000;71(4):450-452. doi:https://doi.org/10.1016/S0367326X(00)00150-7

61. Chen Y, Zhou C, Ge Z, et al. Composition and potential anticancer activities of essential oils obtained from myrrh and frankincense. Oncol Lett. 2013;6(4):1140 1146. doi:10.3892/ol.2013.1520

62. Ukwubile CA, Ahmed A, Katsayal UA, Ya'u J, Mejida S. GC-MS analysis of bioactive compounds from Melastomastrum capitatum (Vahl)Fern. leaf methanol extract: An anticancer plant. Sci African. 2019;3:10-17. doi:10.1016/j. sciaf.2019.e00059

63. Roy RN, Laskar S, Sen SK. Dibutyl phthalate, the bioactive compound produced by Streptomyces albidoflavus 321.2. Microbiol Res. 2006;161(2):121-126. doi:10.1016/j.micres.2005.06.007

64. Li X, Wu Q, Xie Y, et al. Ergosterol purified from medicinal mushroom Amauroderma rude inhibits cancer growth in vitro and in vivo by upregulating multiple tumor suppressors. Oncotarget. 2015;6(19):17832-17846. doi:10.18632/oncotarget.4026

65. Singh K, Bhori M, Kasu YA, Bhat G, Marar T. Antioxidants as precision weapons in war against cancer chemotherapy induced toxicity - Exploring the armoury of obscurity. Saudi Pharm J SPJ Off Publ Saudi Pharm Soc. 2018;26(2):177-190. doi:10.1016/j.jsps.2017.12.013 


\section{GRAPHICAL ABSTRACT}

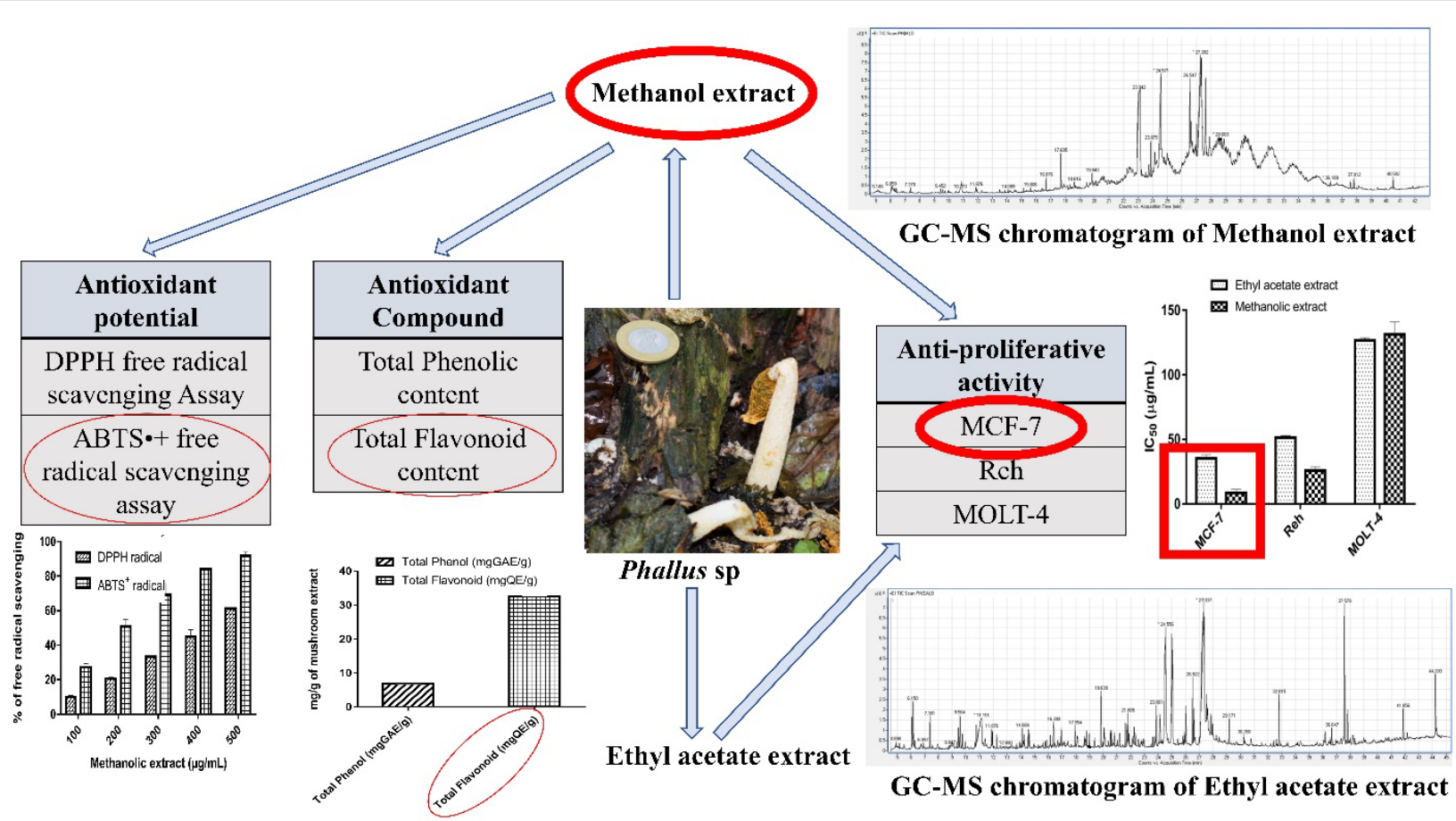

\section{ABOUT AUTHORS}

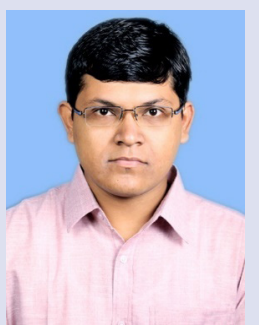

Ribhu Ray is a Junior Research Fellow at the "Laboratory of Cell and Molecular Biology"; Department of Botany; University of Calcutta; West Bengal, India.

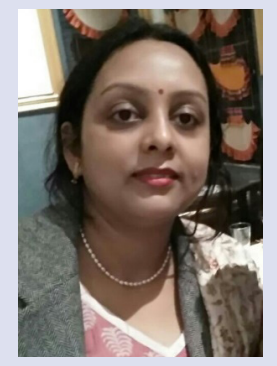

Amrita Pal is a Senior Research Fellow at the "Laboratory of Cell and Molecular Biology"; Department of Botany; University of Calcutta; West Bengal, India.

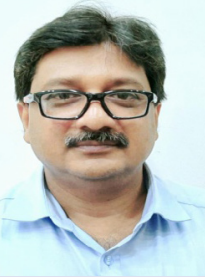

Dr. Santanu Paul is a Professor at the department of Botany, University of Calcutta, India and also the chief of the "Laboratory of Cell and Molecular Biology". He has been working in the field of cancer biology and medicinal plants for two decades. Has immense knowledge and experience in the molecular mechanism of apoptosis induction in cancer cells induced by phyto chemicals and synthetic compounds.

Cite this article: Ray R, Pal A, Paul S. Assessment of the Impact of Wild Stinkhorn Mushroom Extracts on Different Cancer Cell Proliferation and Study of Primary Metabolites. Pharmacogn J. 2020;12(4):699-708. 